\title{
PERUBAHAN BENTUK JARINGAN BIOTA TERDEGRADASI (KERANG HIJAU, RAJUNGAN, DAN BERONANG) DI PERAIRAN KAMAL DAN CILINCING, TELUK JAKARTA
}

\author{
CHANGED OF FORM OF DEGRADADED BIOTA TISSUE \\ (GREEN CLAM, SWIMMING CRAB, AND BERONANG) \\ IN KAMAL AND CILINCING WATERS, JAKARTA BAY
}

\author{
Sri Turni Hartati, Prihatiningsih \& Budi Nugraha
}

Pusat Riset Perikanan, BRSDM KP

Jl. Pasir Putih 2 Ancol Timur, Jakarta Utara; Tlp/Fax: (021) 64700928/(021) 64700929

e-mail : sriturni@yahoo.com

Diterima tanggal: 28 Februari 2020 ; diterima setelah perbaikan: 5 Desember 2020 ; Disetujui tanggal: 15 Desember 2020

\begin{abstract}
ABSTRAK
Teluk Jakarta adalah wilayah perairan yang mengalami eutrifikasi tinggi, status wilayah perairan dapat dipisahkan antara hiper-eutrophic dan eutrophic. Kondisi ini sangat dipengaruhi oleh zat hara hasil dari aktifitas daratan Kota Jakarta yang disalurkan melalui 13 muara sungai ke perairan Teluk Jakarta. Status hiper-eutrophic terdapat pada daerah muara sungai yang dapat menyebabkan tumbuhnya mikroorganisme yang bersifat racun, seperti fenomena alga merah yang menyebabkan terjadinya kematian massal ikan. Kompleksitas kegiatan yang tidak terkendali di Teluk Jakarta mengakibatkan terdegradasinya lingkungan perairan. Dampaknya terhadap sektor perikanan adalah kerusakan habitat dan menurunnya kualitas dan kuantitas sumber daya ikan. Masalah yang sering terjadi adalah kasus kematian ikan masal dan beberapa jenis biota telah terdegradasi, seperti kerang hijau (Perna viridis), rajungan (Portunus pelagicus) dan beronang (Siganus sp). Tulisan ini menyajikan sampai sejauh mana dampak dari pencemaran Teluk Jakarta terhadap sumber daya ikan yang ada, melalui kajian perubahan bentuk mikroanatomi jaringan biota terdegradasi (kerang hijau, rajungan, dan beronang) yang didaratkan di perairan Kamal dan Cilincing. Hasil penelitian menunjukkan bahwa kualitas perairan Teluk Jakarta terutama di muara, sebagian parameter kimiawi sudah melebihi ambang batas baku mutu air, sepert ammonia $\left(\mathrm{NH}_{3}\right)$, phosphat $\left(\mathrm{PO}_{4}\right)$, nitrat $\left(\mathrm{NO}_{3}\right)$, fenol, dan $\mathrm{BOD}_{5}$ dan untuk logam berat yaitu seng $(\mathrm{Zn})$, nikel $(\mathrm{Ni})$, dan tembaga $(\mathrm{Cu})$. Analisis mikroanatomi jaringan insang dan hati pada kerang hijau, rajungan, dan beronang lingkis dari Kepulauan Seribu menunjukkan struktur yang normal dan sampel dari Teluk Jakarta menunjukkan tidak normal atau ada kerusakan, dikatakan telah terdegradasi. Implementasi kebijakan yang direkomendasikan adalah Langkah konkrit harus dilakukan Pemerintah DKI Jakarta adalah membangun IPAL disetiap muara sungai agar air yang bermuara tidak membawa polutan ke laut yang berdampak tercemarnya perairan dan biota di Teluk Jakarta.
\end{abstract}

Kata Kunci: Biota, terdegradasi, Kamal, Cilincing, Teluk Jakarta.

\section{ABSTRACT}

Jakarta Bay is a water area that have high eutrification, the status of territorial waters can be separated between hyper-eutrophic and eutrophic. This condition is greatly influenced by nutrients resulting from the mainland activities of the City of Jakarta which are channeled through 13 river mouths to the waters of Jakarta Bay. Hyper-eutrophic status is found in river mouth areas which can cause the growth of toxic microorganisms, such as the phenomenon of red algae which causes mass death of fish. The complexity of uncontrolled activities in Jakarta Bay results in the degradation of the aquatic environment. The impact on the fisheries sector is habitat destruction and declining quality and quantity of fish resources. The problem that often occurs is the case of mass death of fish and several types of biota have been degraded, such as green clam (Perna viridis), swimming crab (Portunus pelagicus) and beronang (Siganus sp). This paper presents the extent of the impact of Jakarta Bay pollution on existing fish resources, through a study of changes in the form of microanatomized degraded biota tissue (green clams, swimming crabs, and beronang) landed in Kamal and Cilincing waters. The results 
showed that the quality of Jakarta Bay waters especially in the estuary, some chemical parameters had exceeded the water quality standard, such as ammonia $\left(\mathrm{NH}_{3}\right)$, phosphate $\left(\mathrm{PO}_{4}\right)$, nitrate $\left(\mathrm{NO}_{3}\right)$, phenol, and $\mathrm{BOD}_{5}$ and also for heavy metals namely zinc (Zn), nickel (Ni), and cuprum (Cu). Microanatomic analysis of gill and liver tissue in green clams, swimming crab, and beronang from Kepulauan Seribu showed normal structure and samples from Jakarta Bay showed abnormal or damaged, said to have been degraded. The recommended policy implementation is the concrete step that must be taken by the DKI Jakarta Government is to build WWTPs in each river mouth so that the water that flows does not carry pollutants to the sea which results in pollution of waters and biota in the Jakarta Bay.

Keywords: Biota, degraded, Kamal, Cilincing, Jakarta Bay.

\section{PENDAHULUAN}

Perairan Kamal dan Cilincing terletak di barat dan timurTeluk Jakarta dan merupakan daerah penangkapan ikan (fishing ground) bagi nelayan tradisional pantai utara Jawa Barat dan Jakarta. Pengamatan hasil tangkapan dari 13 jenis alat tangkap yang melakukan kegiatan penangkapan di Teluk Jakarta teridentifikasi 92 jenis ikan dan non ikan yang terbagi ke dalam 33 famili. Jenis sumber daya ikan "icon" Teluk Jakarta adalah kerang hijau (Perna viridis), rajungan (Portunus pelagicus) dan beronang (Siganus sp.) (BRPL, 2006).

Menurut Damar (2003) Teluk Jakarta adalah wilayah perairan yang mengalami eutrifikasi tinggi. Status wilayah perairan yang dapat dipisahkan antara wilayah perairan dengan hiper-eutrophic dan eutrophic. Kondisi ini sangat dipengaruhi oleh zat hara hasil dari aktifitas daratan Kota Jakarta yang disalurkan melalui 13 muara sungai ke perairan Teluk Jakarta. Status eutrophic adalah merupakan wilayah yang subur karena terdapat banyak sumber makanan bagi biota laut yang hidup di dalamnya. Sebaliknya status hipereutrophic yang biasanya terdapat pada daerah muara sungai merupakan wilayah yang tidak baik untuk biota laut karena terlalu subur sehingga akan tumbuh mikroorganisme yang bersifat racun, seperti fenomena alga merah yang mematikan ikan.

Teluk Jakarta memiliki peranan yang sangat besar bagi perkembangan perekonomian Indonesia. Sebagai pintu gerbang masuk ibukota, wilayah ini telah dimanfaatkan oleh berbagai sektor. Kawasan pantai Teluk Jakarta sepanjang $32 \mathrm{~km}$ sebagai pusat aktivitas sosial ekonomi skala besar, seperti Pelabuhan Tanjung Priok yang melayani jasa transportasi baik penumpang maupun peti kemas, aktivitas industri, bongkar muat kayu, pendaratan ikan, pergudangan dan pariwisata, yang berakibat sebagai pemasok polutan utama. Pemukiman kumuh dan liar serta aktivitas perikanan di muaramuara sungai selain menghasilkan limbah juga menyebabkan sedimentasi (Soebagio, 2001).
Kegiatan berbagai sektor yang tidak terkendali tentunya akan mengakibatkan terdegradasinya lingkungan perairan. Dampaknya terhadap sektor perikanan adalah kerusakan habitat dan menurunnya kualitas dan kuantitas sumber daya ikan. Masalah yang sering terjadi adalah kasus kematian ikan massal dan beberapa jenis biota telah terdegradasi, seperti kerang hijau (Perna viridis) menjadi lebih rentan terhadap lingkungan, rajungan (Portunus pelagicus) dan beronang (Siganus sp) adanya bercak hitam di bagian abdomen yang menandakan terkena limbah, sehingga pada saat ini tidak terseleksi untuk ekspor yang sudah dilakukan selama beberapa tahun terakhir (BRPL. 2007).

Tulisan ini menyajikan sampai sejauh mana dampak dari pencemaran Teluk Jakarta terhadap sumber daya ikan yang ada, melalui kajian perubahan bentuk mikroanatomi jaringan biota terdegradasi (kerang hijau, rajungan, dan beronang) yang didaratkan di perairan Kamal dan Cilincing.

\section{BAHAN DAN METODE}

Pengambilan sampel kerang hijau, rajungan dan beronang di TPI Kamal dan Cilincing (Teluk Jakarta), diasumsikan sebagai biota yang telah terdegradasi, dan perairan Pulau Laki dan Pulau Pari (Kepulauan Seribu), diasumsikan sebagai biota yang belum terdegradasi. Pengamatan kualitas perairan disajikan atas kerjasama dengan Dinas Lingkungan Hidup Jakarta Provinsi DKI (Gambar 1).

Setelah dilakukan pengukuran panjang dan berat, serta pengambilan sampel insang dan hati dari kerang hijau, rajungan, dan beronang di lokasi survei, preparasi jaringan ke dua organ tersebut dilakukan di Laboratorium BRPL, dan dilanjutkan dengan pemotretan preparat. Data panjang dan berat ikan digunakan untuk menentukan sebaran ukuran panjang dan modusnya, serta hubungan panjang berat yang menggambarkan pola pertumbuhan ikan, dengan 


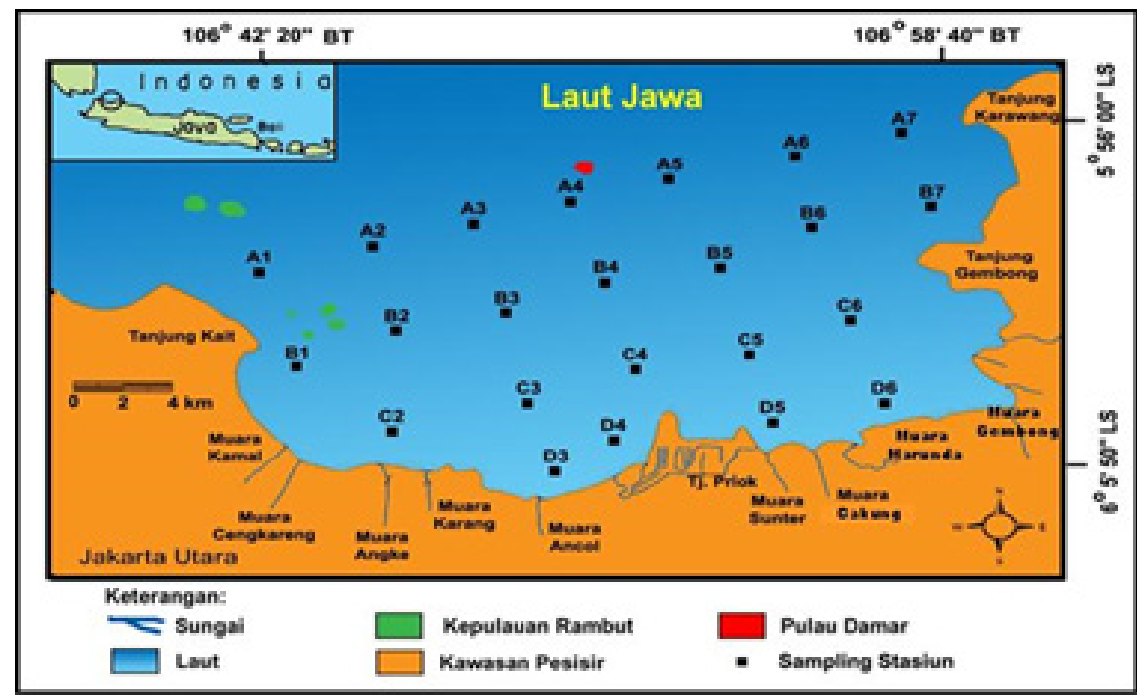

Gambar 1. Stasiun pengamatan kualitas perairan di Teluk Jakarta Figure 1. Water quality observation station in Jakarta Bay

menggunakan rumus Hille (1936) dalam Effendie (1997):

$W=a L^{b}$

dimana,

$W \quad=$ Berat ikan

$L \quad=$ Panjang ikan

$a$ dan $b=$ Konstanta

Analisa yang dilakukan dengan menggunakan analisa deskriptif yang bertujuan untuk menggambarkan bentuk mikro anatomi jaringan dari organ insang dan hati biota yang terdegradasi dengan yang tidak terdegradasi dilakukan di Laboratorium Histologi Fakultas Kedokteran Hewan IPB.

\section{HASIL DAN PEMBAHASAN}

\section{Kualitas Perairan}

Berdasarkan Keputusan Menteri Negara Lingkungan Hidup No. 51 Tahun 2004 tentang Baku Mutu Air Laut, beberapa parameter lingkungan sudah melebihi ambang batas baku mutu untuk biota laut. Konsentrasi padatan tersuspensi total (TSS) di laut pada kisaran antara 2-7 mg/l, di muara pada saat pasang 10-107 $\mathrm{mg} / \mathrm{l}$, dan saat surut $25-112 \mathrm{mg} / \mathrm{l}$. Nilai baku mutu TSS untuk biota laut adalah pada ekosistem karang 20 $\mathrm{mg} / \mathrm{l}$, bakau $80 \mathrm{mg} / \mathrm{l}$ dan lamun $20 \mathrm{mg} / \mathrm{l}$. Pada Gambar 2 dan 3 terlihat bahwa konsentrasi TSS di laut masih di bawah baku mutu, berbeda dengan perairan muara beberapa stasiun sudah melebihi.

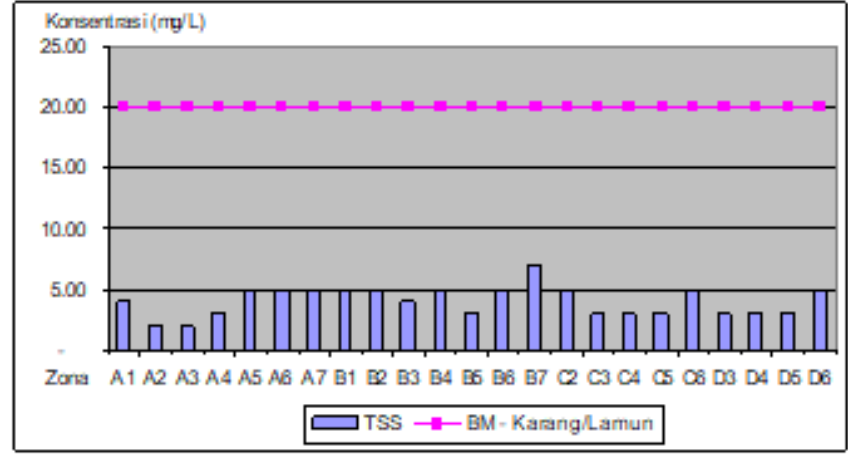

Gambar 2. Konsentrasi padatan tersuspensi total (TSS) di laut Teluk Jakarta bulan Juni 2006 dan nilai baku mutu air untuk biota laut.

Figure 2. Concentration of total suspended solids (TSS) at the sea of Jakarta Bay in June 2006 and water quality standard values for marine biota.

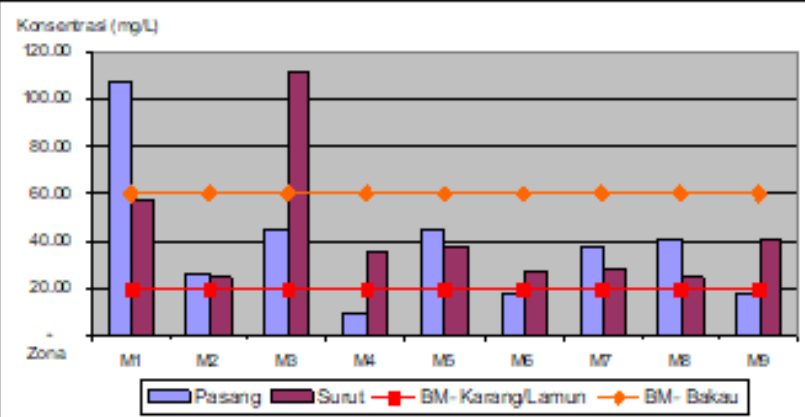

Gambar 3. Konsentrasi padatan tersuspensi total di muara Teluk Jakarta bulan Juni 2006 dan nilai baku mutu untuk biota laut.

Figure 3. Concentration of total suspended solids at the river mouth of Jakarta Bay in June 2006 and quality standard values for marine biota. 
Konsentrasi ammonia $\left(\mathrm{NH}_{3-} \mathrm{N}\right)$ di laut pada kisaran $0,026-0,541 \mathrm{mg} / 1$, di muara pada saat pasang 0,068 $-12,43 \mathrm{mg} / \mathrm{l}$ dan saat surut $0,065-14,73 \mathrm{mg} / \mathrm{l}$. Baku mutu konsentrasi ammonia adalah $0,3 \mathrm{mg} / \mathrm{l}$. Pada Gambar 4 terlihat bahwa konsentrasi ammonia di laut masih di bawah baku mutu, terkecuali pada stasiun C2. Berbeda dengan di muara, bahwa hampir semua stasiun pengamatan sudah melebihi ambang baku mutu, terkecuali stasiun M9 yang berada di ujung timur Teluk Jakarta nilai konsentrasi ammonia masih dibawah ambang baku mutu (Gambar 5).

Konsentrasi fenol di laut pada kisaran 0-0,010 mg/l, di muara saat pasang $0,005-0,010 \mathrm{mg} / 1$ dan surut 0,002 $0,010 \mathrm{mg} / \mathrm{l}$. Nilai baku mutu fenol $0,002 \mathrm{mg} / \mathrm{l}$. Gambar 6 menunjukkan bahwa stasiun pengamatan yang tidak terdeteksi berada 20 mil dari pantai Teluk Jakarta, dan Gambar 7 menunjukkan konsentrasi fenol di muara sudah melebihi nilai baku mutu.

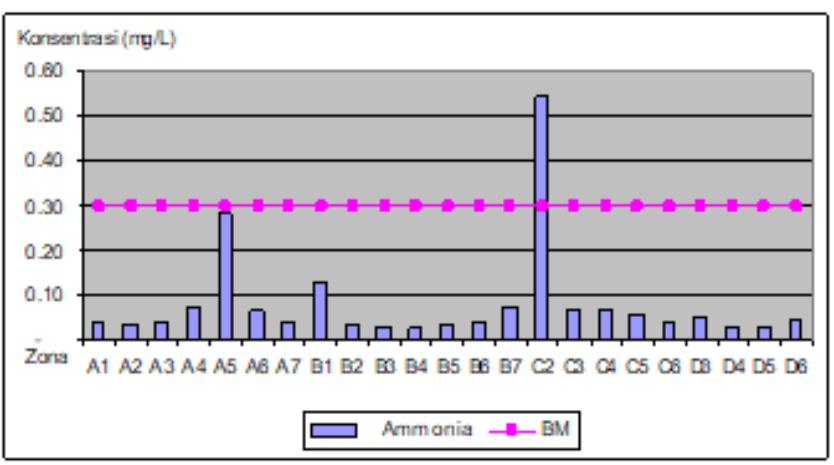

Gambar 4. Konsentrasi ammonia di laut Teluk Jakarta pada bulan Juni 2006 dan nilai baku mutu ammonia.

Figure 4. Ammonia concentration at the sea of Jakarta Bay in June 2006 and quality standard values for ammonia.

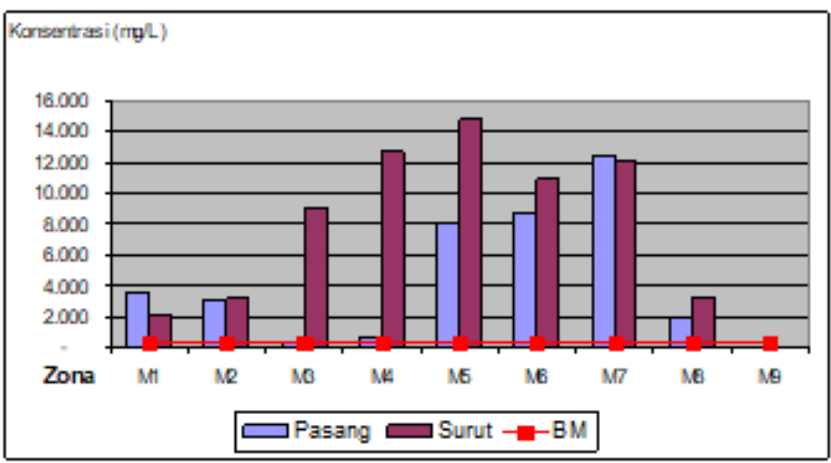

Gambar 5. Konsentrasi ammonia di muara Teluk Jakarta bulan Juni 2006 dan nilai baku mutu ammonia.

Figure 5. Ammonia concentration at the river mouth of Jakarta Bay in June 2006 and quality standard values for ammonia.

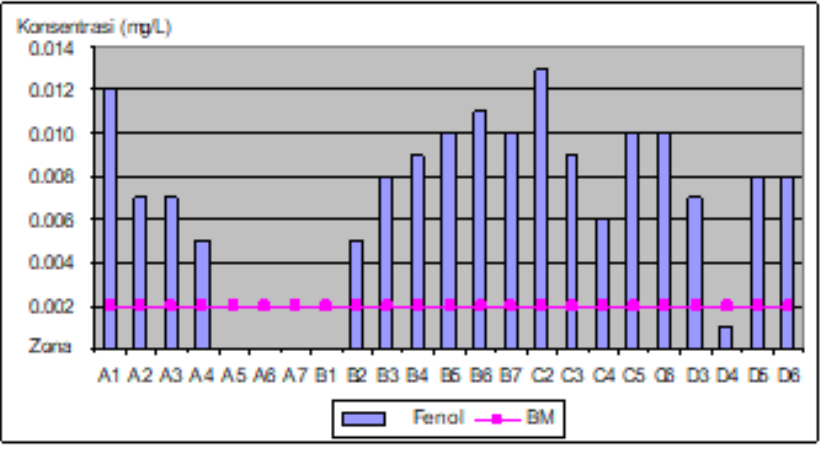

Gambar 6. Konsentrasi fenol di laut Teluk Jakarta pada bulan Juni 2006 dan nilai baku mutu fenol.

Figure 6. Phenol concentration at the sea of Jakarta Bay in June 2006 and quality standard values for phenol.

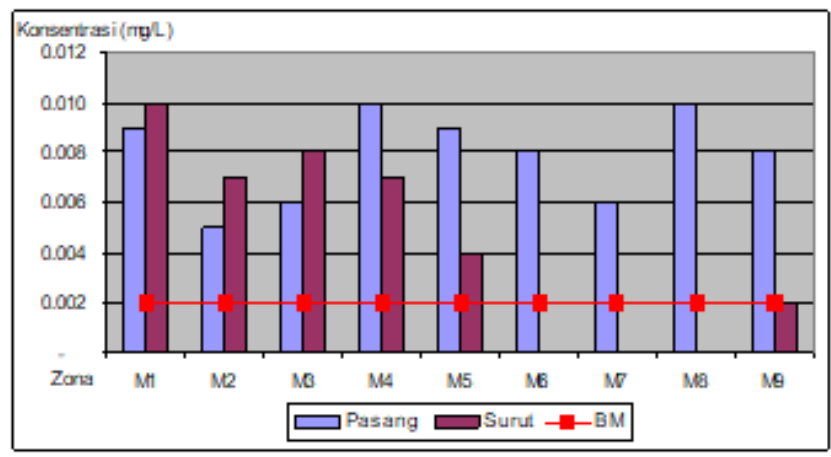

Gambar 7. Konsentrasi fenol di muara Teluk Jakarta pada bulan Juni 2006 dan nilai baku mutu fenol

Figure 7. Phenol concentration at the river mouth of Jakarta Bay in June 2006 and quality standard values for phenol.

\section{Senyawa Phosphat $\left(\mathrm{PO}_{4-} \mathrm{P}\right)$}

Konsentrasi senyawa phosphat di Laut Teluk Jakarta adalah dari $0-0,067 \mathrm{mg} / \mathrm{l}$, di muara pada saat pasang $0,081-1,593 \mathrm{mg} / \mathrm{l}$ dan saat surut $0,051-1,305 \mathrm{mg} / \mathrm{l}$. Nilai baku mutu phosphat adalah $0,015 \mathrm{mg} / \mathrm{l}$. Pada Gambar 8 dan 9 terlihat bahwa di laut hampir semua stasiun pengamatan konsentrasi phosphat di bawah baku mutu, terkecuali stasiun $\mathrm{C} 2$, dan di muara semua stasiun pengamatan pada saat pasang dan surut konsentrasi phosphat sudah melebihi baku mutu.

BOD $_{5}$

BOD adalah banyaknya oksigen yang dibutuhkan oleh mikro-organisme untuk menguraikan bahan organik. Limbah domestik umumnya lebih mudah terurai, sedangkan limbah pertanian, pertambangan dan industri sulit terurai. Konsentrasi $\mathrm{BOD}_{5}$ di laut pada bulan Juni 2006 pada kisaran 27,10-64,00 mg/l, di muara saat pasang $23,20-75,50 \mathrm{mg} / \mathrm{l}$, dan saat surut 21,85-70,95 mg/l. Nilai baku mutu BOD $_{5}$ adalah 20, dengan demikian konsentrasi $\mathrm{BOD}_{5}$ di laut dan muara sudah melebihi baku mutu (Gambar 10 dan 11). 


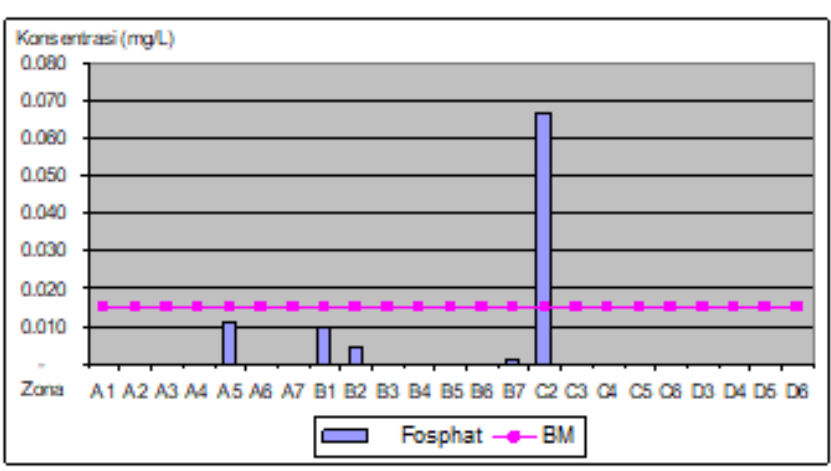

Gambar 8. Konsentrasi phosphat di laut Teluk Jakarta pada bulan Juni 2006 dan nilai baku mutu phosphat.

Figure 8. Phosphate concentration at the sea of Jakarta Bay in June 2006 and quality standard values for phosphate.

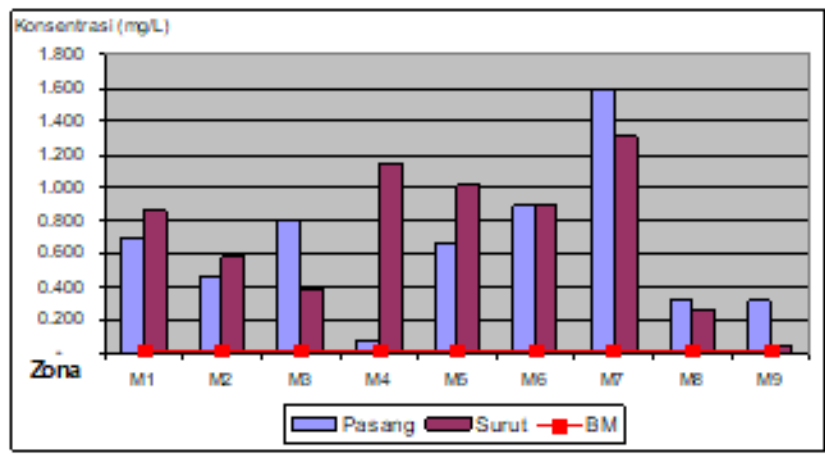

Gambar 9. Konsentrasi phosphat di muara Teluk Jakarta pada bulan Juni 2006 dan nilai baku mutu phosphat.

Figure 9. Phosphate concentration at the river mouth of Jakarta Bay in June 2006 and quality standard values for phosphate.

\section{Deterjen (Surfaktan)}

Konsentrasi deterjen di laut pada bulan Juni 2006 pada kisaran 0,057-0,232 mg/l, di muara saat pasang 0,022 $-3,350 \mathrm{mg} / \mathrm{l}$, saat surut $0,095-4,519 \mathrm{mg} / \mathrm{l}$. Nilai baku mutu $1 \mathrm{mg} / \mathrm{l}$, dengan demikian konsentrasi deterjen di laut masih di bawah batas baku mutu, sedangkan di muara beberapa stasiun sudah melebihi (Gambar 12 dan 13).

Nilai beberapa parameter kimiawi sudah melebihi ambang batas baku mutu untuk biota laut, seperti ammonia $\left(\mathrm{NH}_{3}\right)$, phosphat $\left(\mathrm{PO}_{4}\right)$, nitrat $\left(\mathrm{NO}_{3}\right)$, fenol, dan $\mathrm{BOD}_{5}$. Oksigen terlarut sebagai barometer terpolusinya atau tidak suatu perairan, konsentrasi di perairan muara Teluk Jakarta di bawah batas yang dibutuhkan untuk kehidupan organisme. Tidak demikian dengan di laut, sebagian besar stasiun penelitian konsentrasinya sudah melebihi ambang batas yang dibutuhkan. Oksigen terlarut merupakan

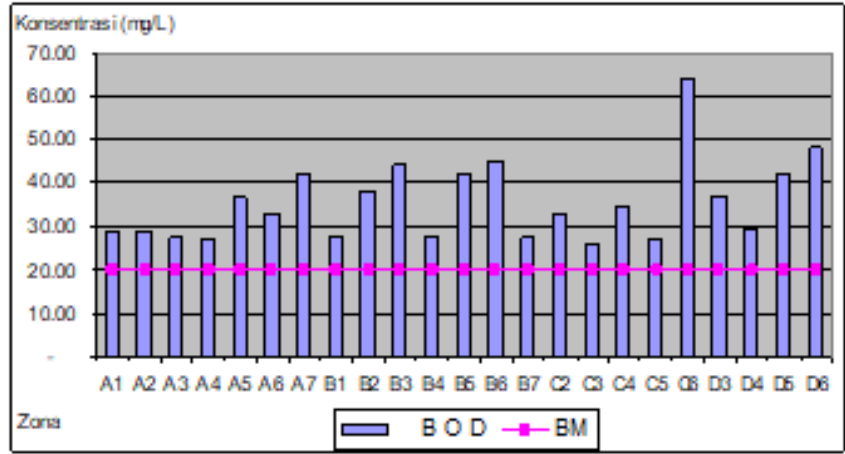

Gambar 10. Konsentrasi BOD di laut Teluk Jakarta pada bulan Juni 2006 dan nilai baku mutu $\mathrm{BOD}_{5}$.

Figure 10. $\mathrm{BOD}_{5}$ concentration at the sea of Jakarta Bay in June 2006 and quality standard values for $B O D_{5}$.

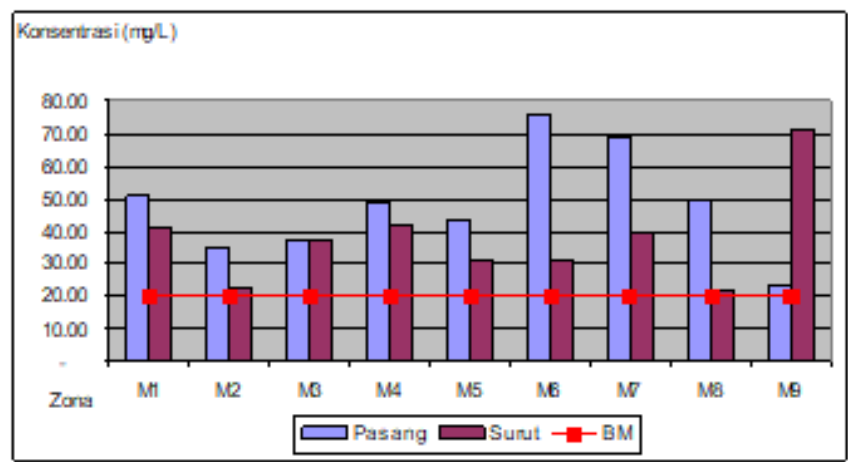

Gambar 11. Konsentrasi BOD 5 di muara Teluk Jakarta bulan Juni 2006 dan nilai baku mutu BOD .

Figure 11. $\mathrm{BOD}_{5}$ concentration at the river mouth of Jakarta Bay in June 2006 and quality standard values for $B O D_{5}$

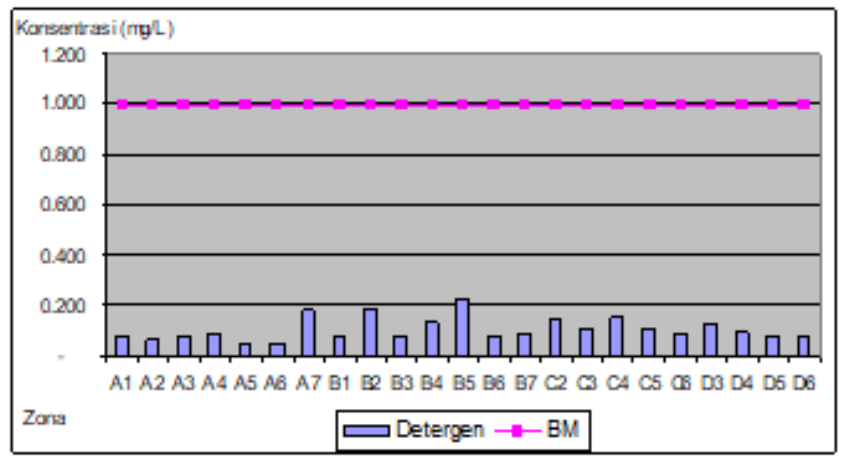

Gambar 12. Konsentrasi deterjen di laut Teluk Jakarta dan nilai baku mutu deterjen.

Figure 12. Detergent concentration at the sea of Jakarta Bay in June 2006 and quality standard values for detergent. 


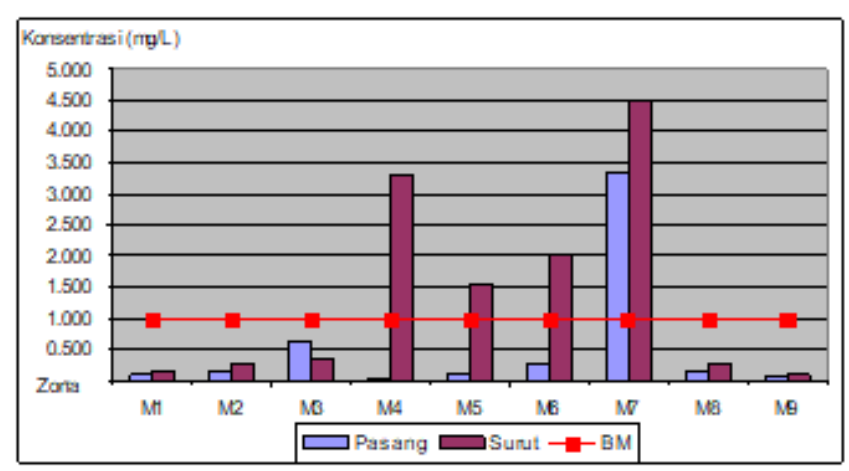

Gambar 13. Konsentrasi deterjen di muara Teluk Jakarta dan nilai BM.

Figure 13. Detergent concentration at the river mouth of Jakarta Bay in June 2006 and quality standard values for detergent. salah satu kebutuhan dasar untuk kehidupan tanaman dan hewan di air. Ikan merupakan makhluk air yang memerlukan oksigen tertinggi, kemudian avertebrata, dan yang terendah adalah bakteri (Fardiaz, 1992). Beberapa unsur logam berat dapat terdeteksi, seperti seng $(\mathrm{Zn})$, nikel $(\mathrm{Ni})$, dan tembaga $(\mathrm{Cu})$ dengan konsentrasi sudah melebihi nilai ambang batas baku mutu. Kondisi fisis air, seperti kekeruhan, zat padat tersuspensi (TSS) dan zat padat terlarut (TDS) sudah melebihi nilai ambang baku mutu (Tabel 1).

\section{Mikroanatomi Insang Kerang hijau}

Insang atau ctenidia pada kerang hijau berjumlah dua pasang dan terletak di kanan dan kiri. Keduanya

Tabel 2. Data kualitas perairan Teluk Jakarta dan Baku Mutu untuk biota laut menurut Keputusan Menteri Negara Lingkungan Hidup No. 51/2004

Table 2. Quality Data of Jakarta Bay waters and Quality Standards for marine biota according to Decree of the Minister of Environment No. 51/2004

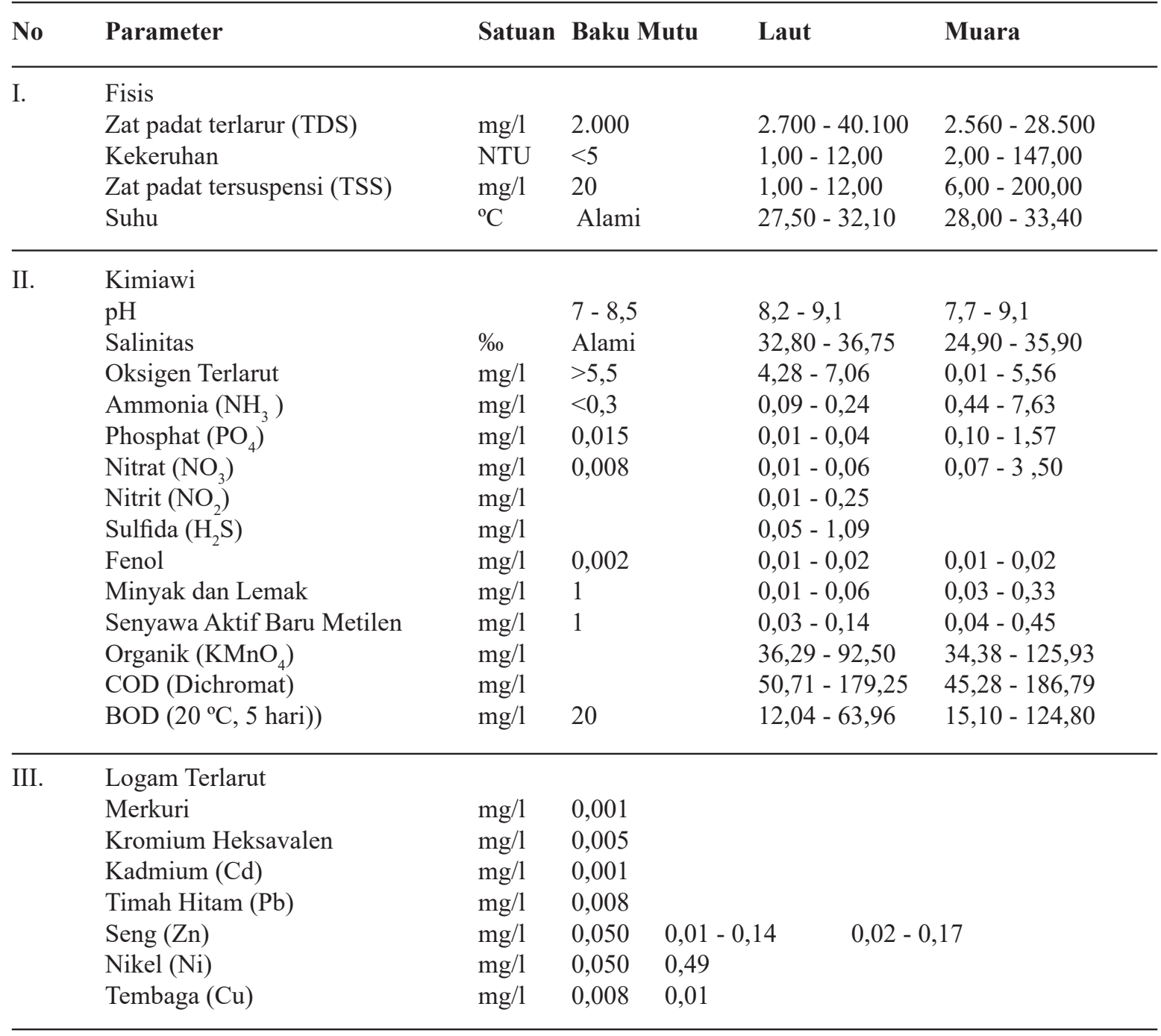


terletak di sebelah posterior rongga mantel dalam posisi lateral. Insang pada kerang hijau terdiri dari deretan filamen yang tersusun secara longitudinal membentuk lembaran insang atau ctenidia (Widiyanti et al., 2005). Filamen yang berdekatan satu dengan yang lainnya dihubungkan oleh jaringan ciliary junction atau interfilamentous junction. Bagian tepi dorsolateral lembaran filamen luar berhubungan dengan dinding mantel lebih longgar (Widiyanti et al., 2005).

Aryani (2004) mengevaluasi tingkat kerusakan pada insang yang berhubungan dengan pencemaran. Tingkat 1 adalah terjadi edema pada lamela branchialis dan terlepasnya sel epithelium dari jaringan dibawahnya yang menyebabkan epithelium dengan sel pilar terpisah. Kerusakan tingkat 2 hiperplasia pada basis Lamella, tingkat 3 hiperplasia menyebabkan dua lamela sekunder bersatu, tingkat 4 hampir seluruh lemela sekunder mengalami hiperplasia, dan tingkat 5
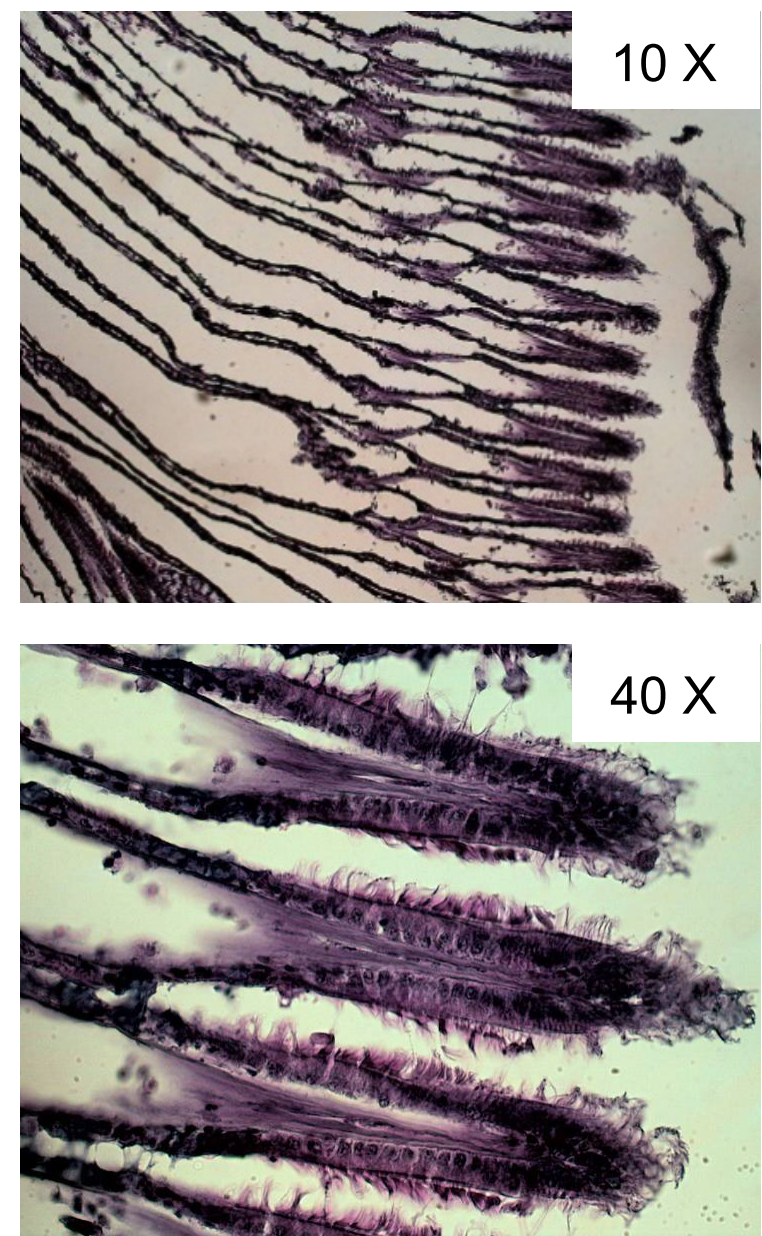

Gambar 14. Potongan melintang struktur mikroanatomi insang kerang hijau (Perna viridis) perairan Kepulauan Seribu.

Figure 14. Cross section of gills microanatomic structure of green clam (Perna viridis) in Kepulauan Seribu waters. hampir seluruh struktur Lamella sekunder mengalami hyperplasia dan mengalami kerusakan filamen.

Berdasarkan pengamatan struktur mikroanatomi insang kerang hijau yang berasal dari Kepulauan Seribu, menunjukkan struktur normal belum terlihat adanya kerusakan (Gambar 14). Sedangkan hasil pengamatan terhadap struktur mikroanatomi dari Teluk Jakarta ditunjukkan pada Gambar 15.

Pada struktur normal, bagian-bagian lamela primer terdiri dari jaringan pengikat, water tubes dan haemal sinuses. Lamela sekunder terdiri dari sel pilar, sel darah dan sel epitelium bersilia. Sel interlamela yang terletak diantara lamela-lamela sekunder. Pada struktur
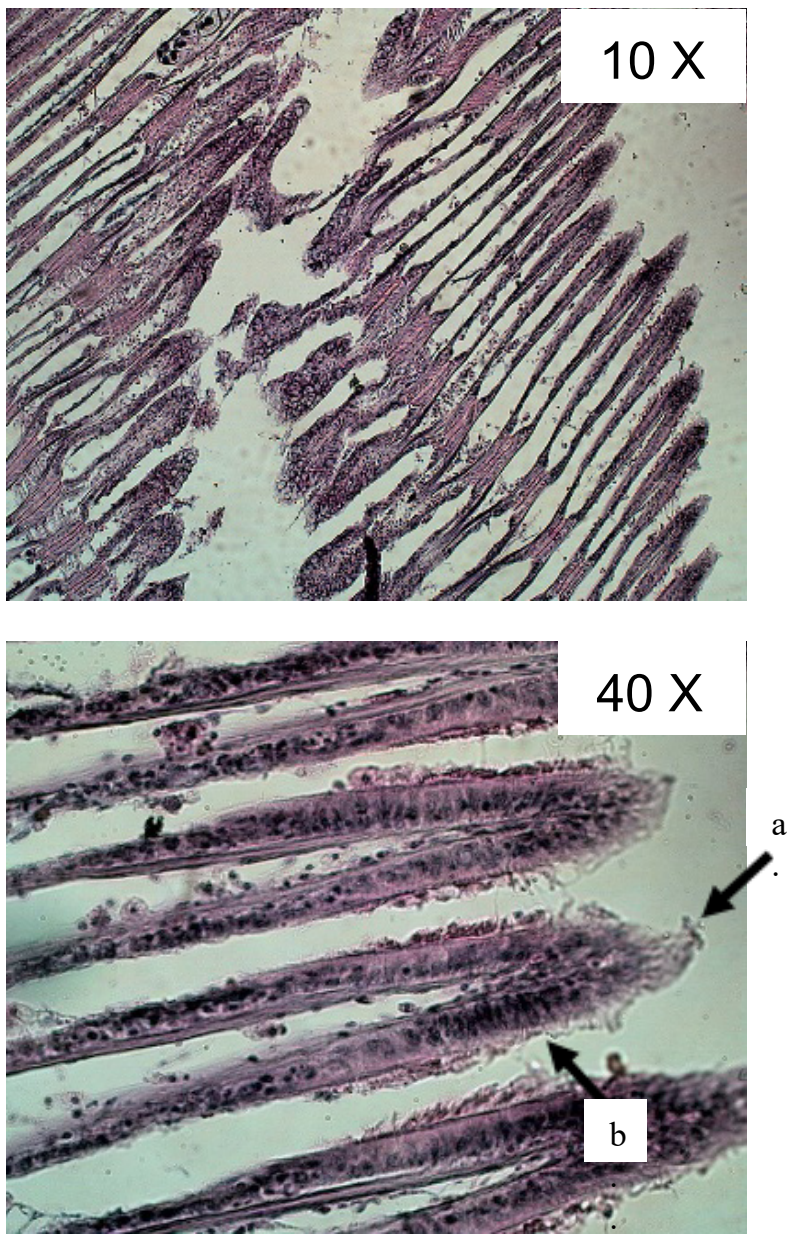

Gambar 15. Potongan melintang struktur mikroanatomi insang kerang hijau (Perna viridis) perairan Teluk Jakarta. Figure 15. Cross section of gills microanatomic structure of green clam (Perna viridis) in Jakarta Bay waters.

Keterangan gambar :

a. Serabut halus (silia) pada ujung insang terlihat berkurang. b. Sel epitel terlepas dari jaringan di bawahnya.

Perubahan Bentuk Jaringan Biota Terdegradasi (Kerang Hijau, Rajungan, dan Beronang) di Perairan Kamal dan Cilincing, Teluk Jakarta - Sri Turni Hartati, Prihatiningsih \& Budi Nugraha 
tersebut, belum terlihat adanya kerusakan.

Hasil pada pengamatan Teluk Jakarta (Gambar 15), menunjukkan jaringan mengalami kerusakan, dimana silia yang terdapat pada Lamella sekunder mengalami kerusakan (a), sehingga terlihat berkurang. Selain itu, pada bagian sel epitel, tampak terlepas dari jaringan di bawahnya (b). Berdasarkan kerusakan tersebut, Aryani (2004) mengkategorikan bahwa jaringan mengalami kerusakan tingkat 1 .

\section{Rajungan}

Hasil pengamatan terhadap struktur mikroanatomi insang rajungan Kepulauan Seribu dan Teluk Jakarta, menunjukkan adanya perbedaan. Pada sampel yang berasal dari Teluk Jakarta, struktur Lamella tampak meluas dan menipis. Sampel Kepulauan Seribu jaringan tampak normal (Gambar 16 dan 17).
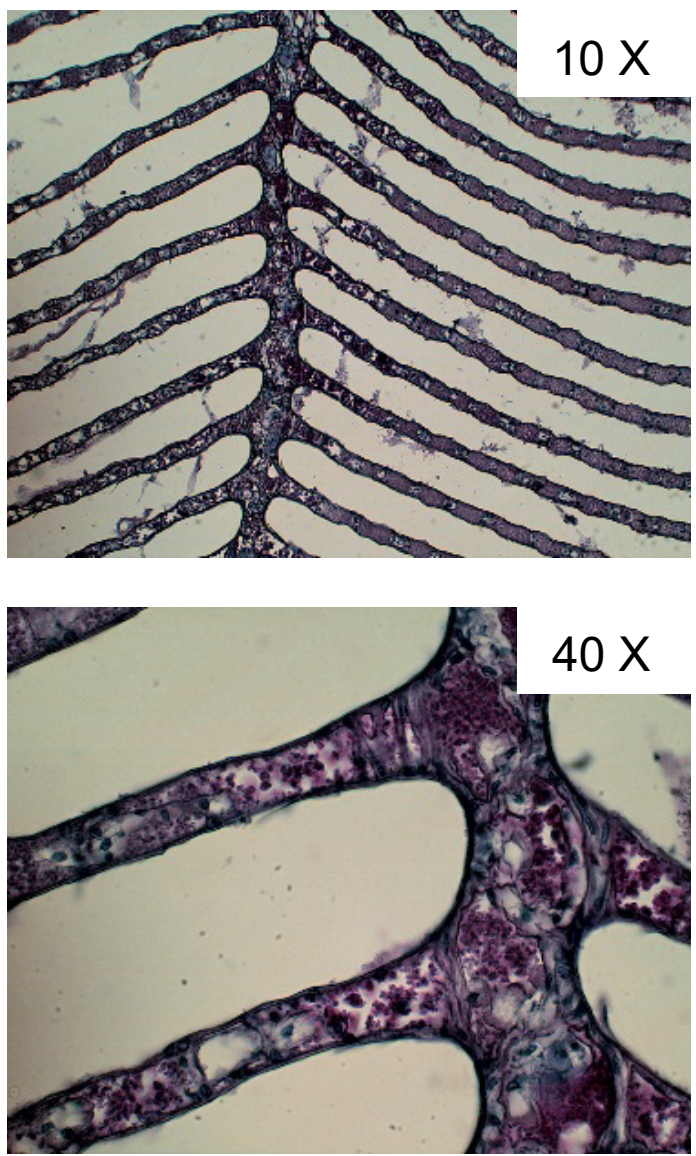

Gambar 16. Potongan melintang struktur mikroanatomi insang rajungan (Portunus pelagicus) perairan Kepulauan Seribu.

Figure 16. Cross section of gills microanatomic structure of swimming crab (Portunus pelagicus) in Kepulauan Seribu waters.

\section{Beronang (Lingkis)}

Pada umumnya ikan mempunyai lima pasang lengkung insang, yaitu empat pasang Lamella primer dan satu pasang Lamella sekunder. Lamella primer bentuknya tipis, berupa dua garis melengkung ke belakang dan saling berhubungan. Lamella sekunder berbentuk setengah lingkaran mengelilingi semua bagian dari Lamella primer (Nurchayatun, 2007).

Insang terdiri dari sepasang filamen insang, dimana setiap filamen terdiri dari serat melintang yang tertutup epithelium yang tipis yang disebut Lamella. Lamella merupakan penyusun filamen. Sebuah rangkaian Lamella pada satu sisi dari septum interbranchiale disebut hemibranchium. Dua hemibranchium dan septum interbranchia membentuk insang lengkap disebut holobranchia. Lamella sekunder insang berupa lipatan lembaran melintang, tipis, dinding luarnya terdiri dari selapis sel epithelium pipih dan di bawahnya terdapat lapisan sub epithelium yang sangat
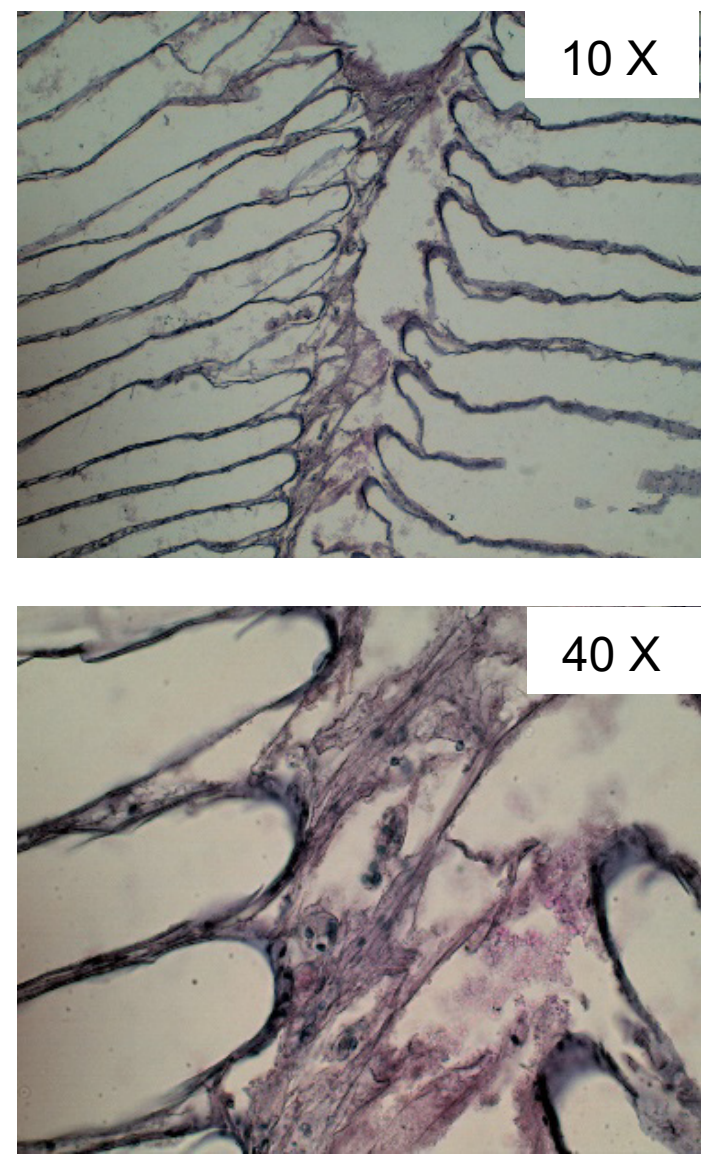

Gambar 17. Potongan melintang struktur mikroanatomi insang rajungan (Portunus pelagicus) perairan Teluk Jakarta.

Figure 17. Cross section of gills microanatomic structure of swimming crab (Portunus pelagicus) in Jakarta Bay waters. 
tipis dan terdiri dari jaringan ikat. Selubung epithelium dibungkus oleh lapisan vaskuler medial, merupakan anyaman kapiler darah dari arteri branchialis efferent sel-sel pilaster dari eritrosit (Nurchayatun, 2007).

Perubahan struktur mikroanatomi insang dapat digunakan sebagai indikator tingkat pencemaran di lingkungan, mulai terjadinya kontaminasi, pencemaran tingkat ringan sampai tingkat berat. Kerusakan insang dari tingkat ringan hingga berat dirumuskan berdasarkan metode Tandjung (1982) sebagai berikut : - Edema (pembengkakan sel) pada Lamella menandakan telah terjadi kontaminasi tetapi belum ada pencemaran.

- Hyperplasia (pembentukan jaringan secara berlebihan) pada pangkal Lamella. Hal ini merupakan gejala pencemaran.

- Fusi dua Lamella (pencemaran tingkat awal).

- Hyperplasia hampir seluruh Lamella sekunder, telah terjadi pencemaran.

- Rusaknya atau hilangnya struktur filamen insang
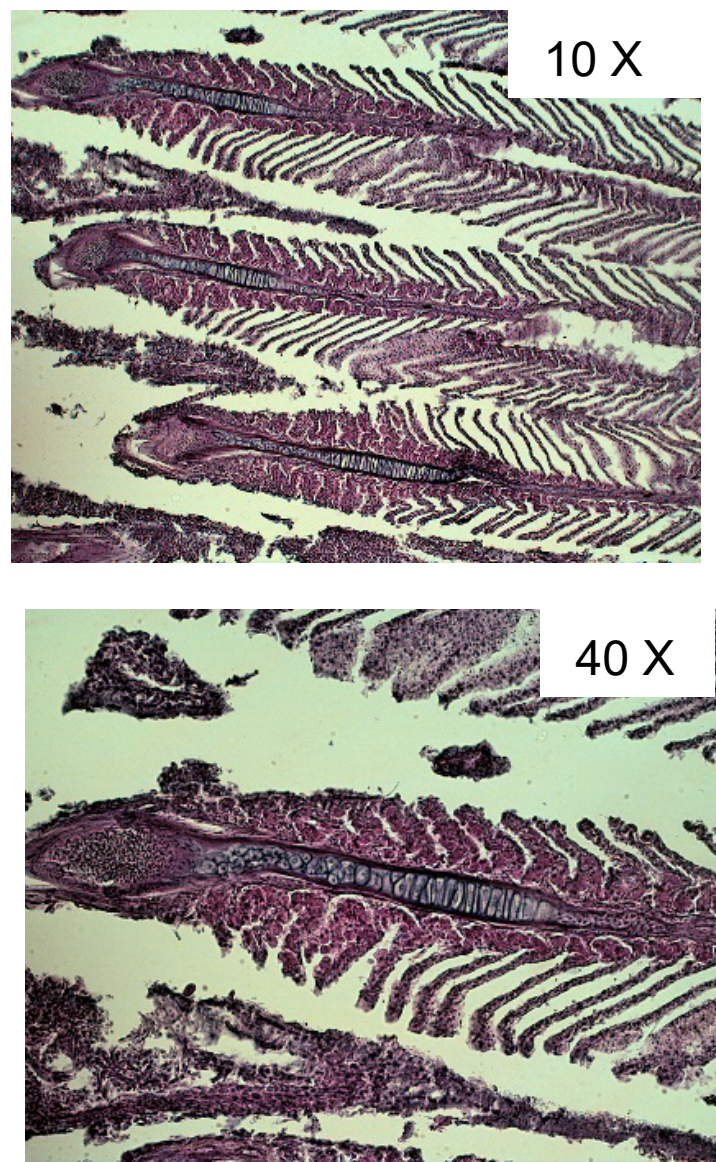

Gambar 18. Potongan melintang struktur mikroanatomi insang beronang lingkis (Siganus canaliculatus) perairan Kepulauan Seribu.

Figure 18. Cross section of gills microanatomic structure of beronang lingkis (Siganus canaliculatus) in Kepulauan Seribu waters. (pencemaran berat).

Hasil pengamatan struktur mikroanatomi insang lingkis dapat dilihat pada Gambar 18 dan 19. Pada struktur mikroanatomi insang, sampel yang berasal dari Kepulauan Seribu masih terlihat normal. Bagian dari struktur insang masih tampak lengkap, pada bagian Lamella primer maupun Lamella sekunder tidak mengalami kerusakan. Pada hasil pengamatan struktur mikroanatomi insang lingkis yang berasal dari Teluk Jakarta, menunjukkan struktur jaringan telah mengalami fusi Lamella. Kerusakan tersebut, menandakan telah terjadi pencemaran tingkat awal. Fusi Lamella sekunder diakibatkan karena adanya pembengkakan pada sel-sel insang (edema). Terjadinya fusi Lamella sekunder mengakibatkan fungsi Lamella sekunder terganggu dalam hal proses pengambilan oksigen sehingga berpengaruh terhadap kematian ikan (Nurchayatun, 2007).
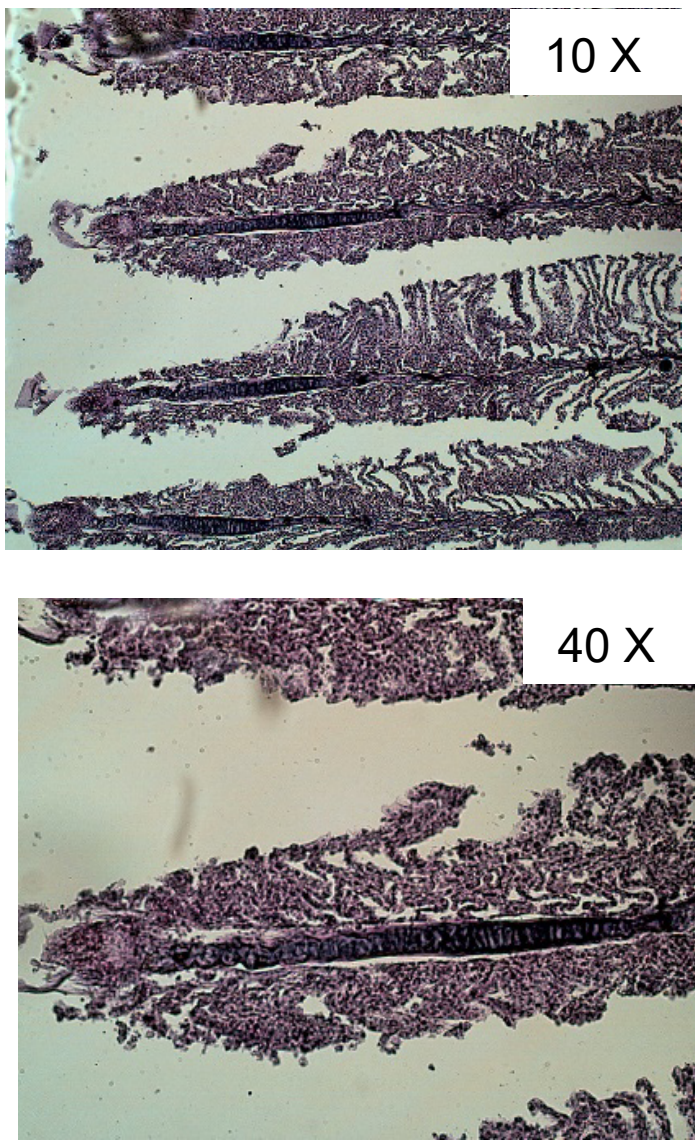

Gambar 19. Potongan melintang struktur mikroanatomi insang lingkis (Siganus canaliculatus) perairan Teluk Jakarta.

Figure 19. Cross section of gills microanatomic structure of beronang lingkis (Siganus canaliculatus) in Jakarta Bay waters.

$\overline{\text { Perubahan Bentuk Jaringan Biota Terdegradasi (Kerang Hijau, Rajungan, dan Beronang) di Perairan Kamal dan Cilincing, }}$ Teluk Jakarta - Sri Turni Hartati, Prihatiningsih \& Budi Nugraha 


\section{Mikroanatomi Hati \\ Kerang hijau}

Struktur mikroanatomi digestive gland (hepar/hati) pada jenis kerang, berbeda dengan struktur hepar pada vertebrata. Pada jenis kerang, hepar tidak berbentuk lobulus tetapi berbentuk asini. Struktur mikroanatomi hepar kerang, masih sangat sederhana, menyerupai struktur glandula digestoria kecil pada vertebrata (Widiyanti et al., 2005).

Gambar 20 menunjukkan struktur mikroanatomi hepar dari kerang hijau Kepulauan Seribu. Pada gambar tersebut, terlihat masih normal, berbentuk asini, dengan komponen myoepitel, inti (nukleus), duktus sekretorius dan granula sekresi.

Sel asini disusun oleh sel-sel penghasil sekret. Sel penghasil sekret berbentuk piramid dengan inti terpulas gelap. Terdapat pula sel myoepitel yaitu sel stelata, terletak diantara sel sekretoris asini dan membran basalis asini. Sel myoepitel kaya dengan mikrofilamen dalam sitoplasma,antara lain adalah
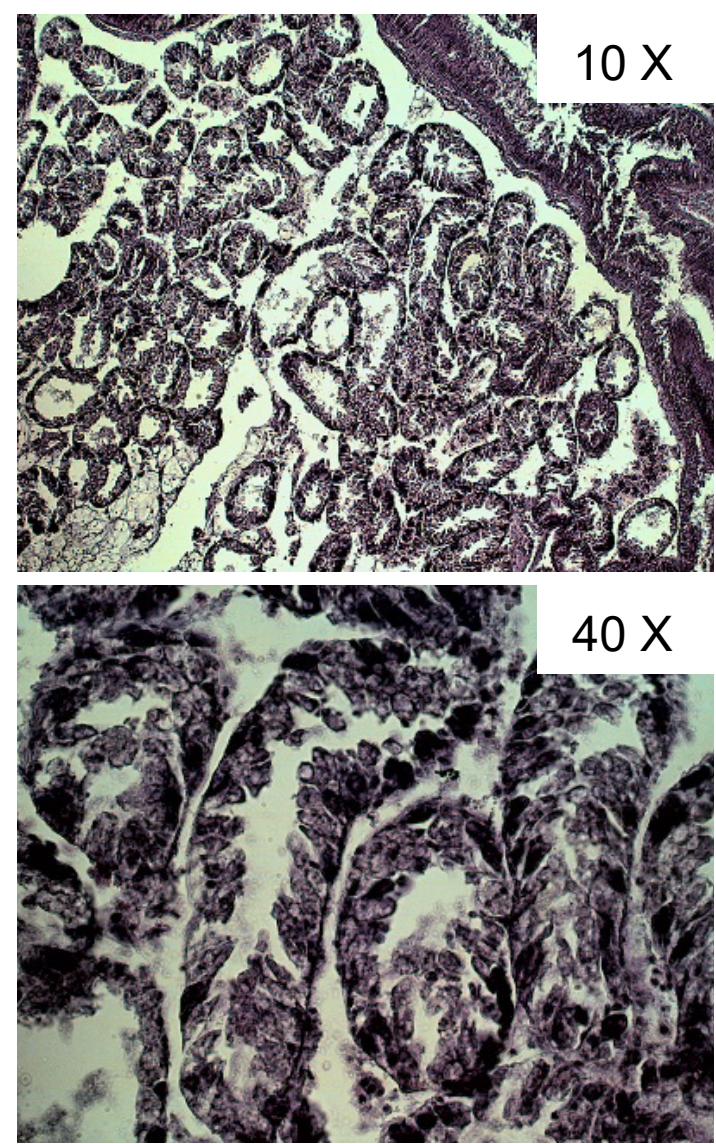

Gambar 20. Potongan melintang struktur mikroanatomi hati kerang hijau (Perna viridis) perairan Kepulauan Seribu. Figure 20. Cross section of heart microanatomic structure of green clam (Perna viridis) in Kepulauan Seribu waters.
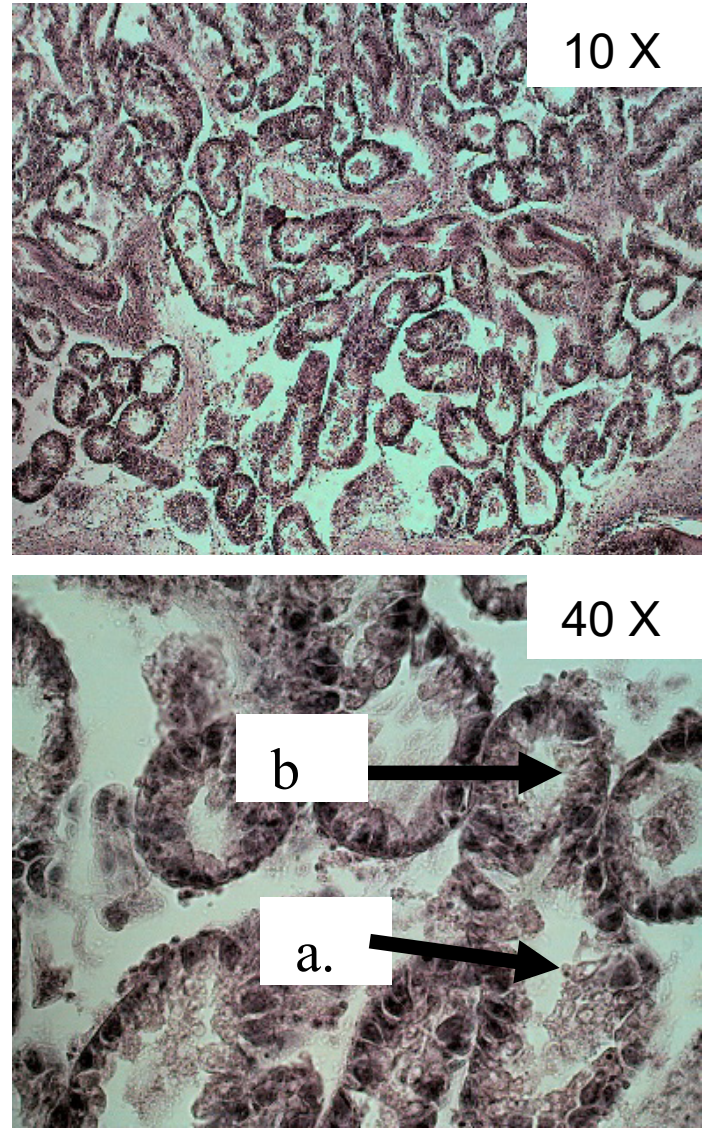

Gambar 21. Potongan melintang struktur mikroanatomi hati kerang hijau (Perna viridis) perairan Teluk Jakarta.

Figure 21. Cross section of heart microanatomic structure of green clam (Perna viridis) in Jakarta Bay waters.

aktin, dan merupakan unsur kontraktil yang membantu memeras hasil sekresi asini (Widiyanti et al., 2005). Hasil pengamatan terhadap struktur mikroanatomi hati kerang hijau Teluk Jakarta, menunjukkan adanya perbedaan dari jaringan normal. Kerusakan yang nampak adalah terjadinya sitolisis kerusakan (a) dan karyolisis kerusakan inti sel (b) pada struktur jaringannya (Gambar 21).

\section{Rajungan}

Hasil pengamatan terhadap struktur mikroanatomi hati rajungan disajikan pada Gambar 22 dan 23. Pada gambar 22, nampak jaringan masih normal, belum terlihat adanya kerusakan jaringan. Gambar 23 menunjukkan struktur mikroanatomi hati rajungan yang berasal dari Teluk Jakarta, sudah mengalami sedikit kerusakan. Perubahan bentuk jaringan tersebut berupa cloudy swelling pada sebagian hepatosit. Perubahan bentuk tersebut merupakan respon fisiologis yang berpotensi 
untuk membentuk suatu kerusakan pada hati.

\section{Beronang/Lingkis}

Sel hati pada ikan, berbentuk polihedral, dengan enam permukaan atau lebih. Sel hati mempunyai satu/dua buah inti bulat, banyak retikulum endoplasma halus dan kasar, serta mempunyai banyak mitokondria yang berbentuk ovoid atau sferis. Sel hati berkelompok dalam lempeng-lempeng dan saling berhubungan sedemikian rupa sehingga membentuk bangunan lobulus hati. Di dalam lobulus hati, sel hati tersusun secara radier (Destiany, 2007). Tingkat kerusakan hati menurut Darmono (1995), yaitu tingkat kerusakan ringan ditandai dengan pembengkakan sel; tingkat kerusakan sedang yaitu kongesti dan hemoragi; sedangkan tingkat berat adalah kematian sel atau nekrosis.
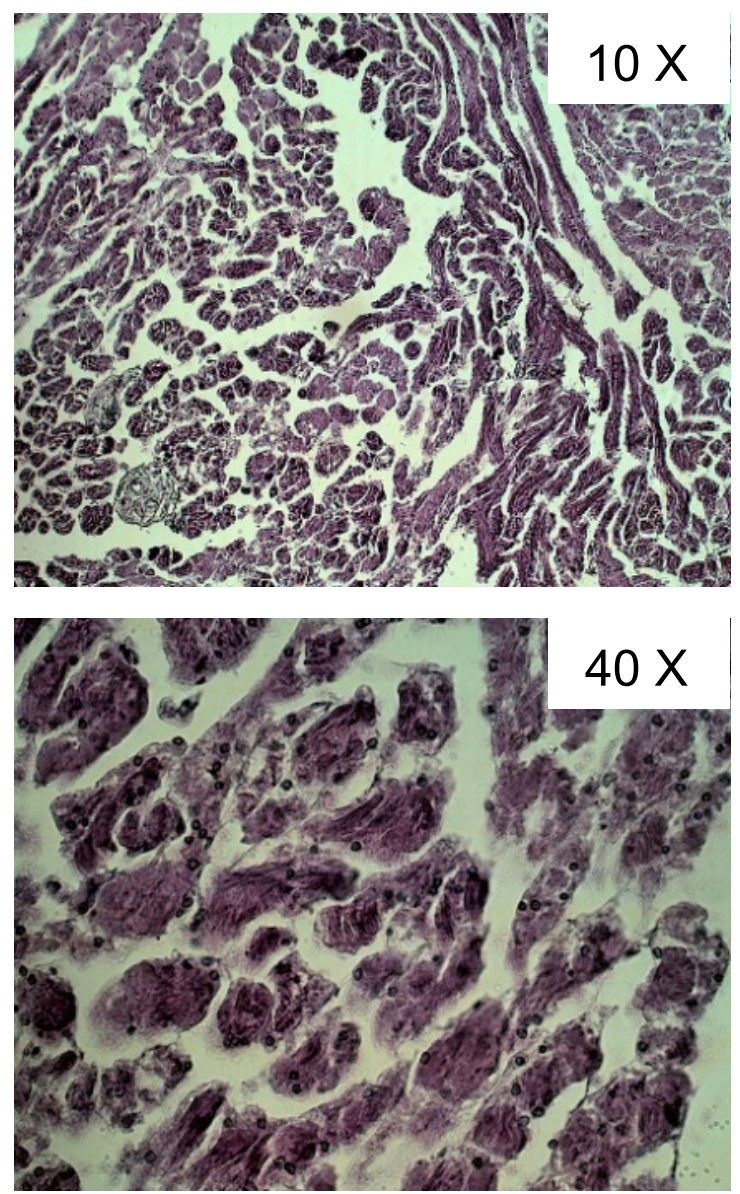

Gambar 22. Potongan melintang struktur mikroanatomi hati rajungan (Portunus pelagicus) perairan Kepulauan Seribu. Figure 22. Cross section of heart microanatomic structure of swimming crab (Portunus pelagicus) in Kepulauan Seribu waters.
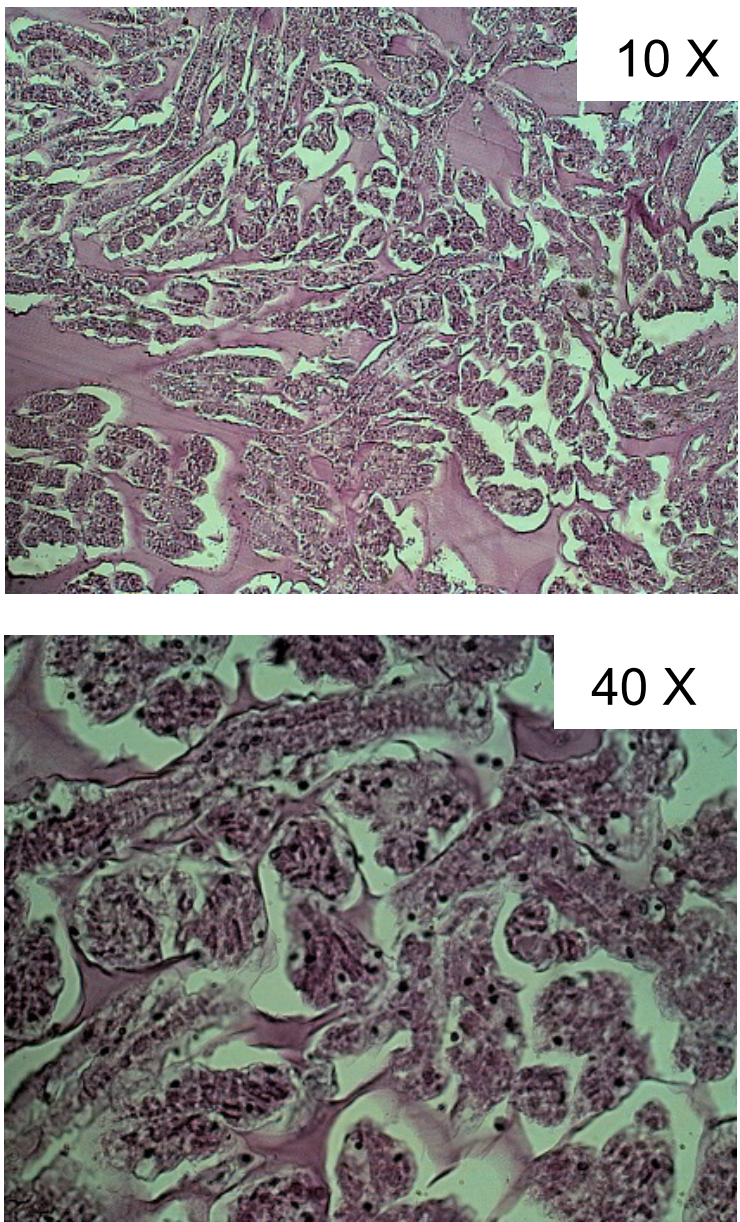

Gambar 23. Potongan melintang struktur mikroanatomi hati rajungan (Portunus pelagicus) perairan Teluk Jakarta.

Figure 23. Cross section of heart microanatomic structure of swimming crab (Portunus pelagicus) in Jakarta Bay waters.

Pada struktur mikroanatomi sel hati beronang lingkis dari Kepulauan Seribu, nampak terlihat normal. Hepatosit berbentuk polihedral, sitoplasma terpulas merah muda, inti bulat hingga oval letaknya sentralis dan sinusoid tampak jelas, dan vena sentralis sebagai pusat lobulus tampak berbentuk bulat dan kosong (Gambar 24). Struktur mikroanatomi sel hati beronang lingkis Teluk Jakarta disajikan pada Gambar 25.

Pada Gambar 25, kerusakan yang terjadi pada jaringan hati lingkis Teluk Jakarta adalah nampak terjadinya kongesti, sehingga dapat dikatakan jaringan tersebut, termasuk ke dalam tingkat kerusakan sedang. Kongesti adalah pembendungan darah yang disebabkan karena gangguan sirkulasi yang dapat mengakibatkan kekurangan oksigen dan zat gizi. 

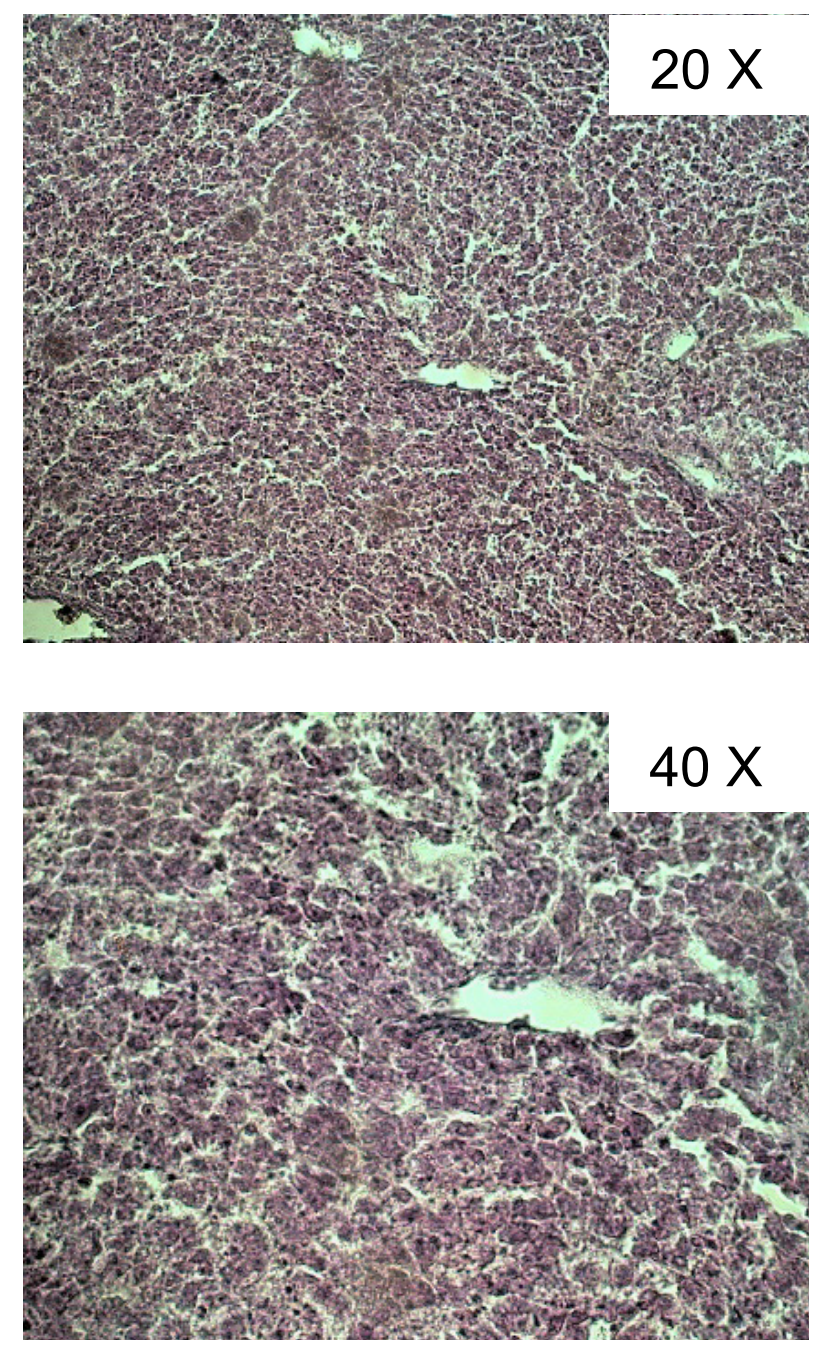

Gambar 24. Potongan melintang struktur mikroanatomi hati beronang lingkis (Siganus canaliculatus) perairan Kepulauan Seribu.

Figure 24. Cross section of heart microanatomic structure of beronang lingkis (Siganus canaliculatus) in Kepulauan Seribu waters.

\section{KESIMPULAN DAN SARAN}

\section{Kesimpulan}

1. Kualitas air di perairan Teluk Jakarta khususnya di wilayah muara, sebagian besar parameter kimiawi sudah melebihi ambang batas baku mutu air, diantaranya adalah ammonia $\left(\mathrm{NH}_{3}\right)$, phosphat $\left(\mathrm{PO}_{4}\right)$, nitrat $\left(\mathrm{NO}_{3}\right)$, fenol, dan $\mathrm{BOD}_{5}$; sedangkan untuk logam berat yang terdeteksi melebihi ambang batas untuk biota air diantaranya adalah seng $(\mathrm{Zn})$, nikel $(\mathrm{Ni})$, dan tembaga $(\mathrm{Cu})$.

2. Bentuk jaringan insang dan hati pada kerang hijau, rajungan, dan beronang/lingkis Kepulauan Seribu, menunjukkan struktur yang normal. Sampel dari
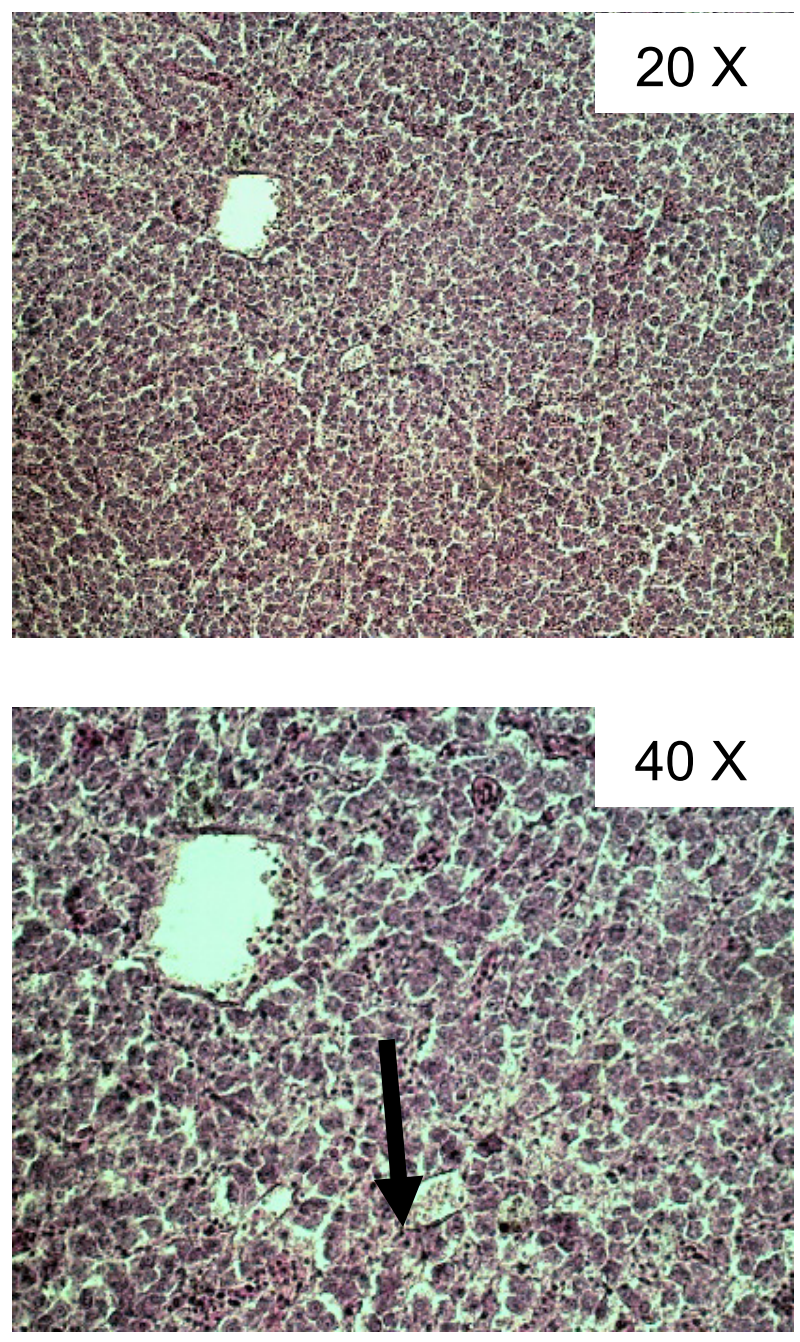

Gambar 25. Potongan melintang struktur mikroanatomi hati lingkis (Siganus canaliculatus) perairan Teluk Jakarta. Figure 25. Cross section of heart microanatomic structure of beronang lingkis (Siganus canaliculatus) in Jakarta Bay waters.

Teluk Jakarta dapat dikatakan telah terdegradasi, ditunjukkan dengan adanya kerusakan jaringan insang dan hati.

\section{Rekomendasi}

Langkah konkrit yang harus dilakukan Pemerintah DKI Jakarta adalah perbaikan kualitas perairan Teluk Jakarta dengan membangun IPAL di setiap muara sungai agar air yang bermuara tidak membawa polutan ke laut yang berdampak tercemarnya biota perairan Teluk Jakarta. 


\section{UCAPAN TERIMA KASIH}

Ucapan terima kasih ke semua pihak yang telah membantu terlaksananya seluruh kegiatan penelitian sampai selesai.

\section{DAFTAR PUSTAKA}

Aryani, Y. (2004). Toksisitas akut limbah cair pabrik batik CV. Giyanto Santoso Banaran Surakarta dan efek sublethalnya terhadap struktur mikroanatomi Branchia dan Hepar Ikan Nila (Oreochromis niloticus T.). Skripsi. Surakarta : Biologi FMIPA UNS.

BPPL. (2006). Identifikasi kondisi sumberdaya dan lingkungan pada lokasi pemanfaatan lahan perikanan di Teluk Jakarta. Laporan Teknis 2006. Jakarta: Balai Penelitian Perikanan Laut.

BRPL. (2007). Riset sumberdaya ikan dan lingkungan perairan Teluk Jakarta dan Kepulauan Seribu. Laporan Teknis 2007. Jakarta: Balai Penelitian Perikanan Laut.

Damar, A. (2003). Effects of enrichment on nutrient dynamics, phytoplankto dynamics and prmary production in Indonesia tropical waters : A comparison between Jakarta Bay, Lampung Bay and Semangka Bay. Dissertation zur Erlangung des Doktorgrades der MathematischNaturwissenschaftlichen Fakultät der ChristianAlbrechts-Universität zu Kiel.

Darmono. (1995). Logam dalam sistem biologi air. Jakarta: UI Press.

Destiany, M. (2007). Pengaruh pemberian merkuri klorida terhadap struktur mikroanatomi hati Ikan Mas. Skripsi. Universitas Negeri Semarang.

Effendie, M. I. (1997). Biologi perikanan. Yogyakarta: Pustaka Nusatama. 163 p.

Keputusan Menteri Negara Lingkungan Hidup No. 51 tahun 2004 tentang Baku Mutu Air Laut.

Nurchayatun, T. (2007). Pengaruh pemberian merkuri klorida terhadap struktur mikroanatomi insang Ikan Mas. Skripsi. Jurusan Biologi, Fakultas MIPA, Universitas Negeri Semarang.
Fardiaz, S. (1992). Polusi air dan udara. Jogjakarta: Penerbit Kanisius.

Soebagio. (2001). Arahan dan gagasan pembangunan kelautan DKI Jakarta. Himpunan karangan ilmiah di bidang perkotaan dan lingkungan. 3(2).

Tandjung, S. D. (1982). The acute toxicity and histopathology of Brook Trout (Salvelinus fontinales, Mitchell) exponed in aluminium acid water. Dissertation. New Cork: Louis Calder Conservation and Ecology Study Center of Fordham University.

Widiyanti C. A., Sunarto., \& Handajani, N. S. (2005). Kandungan logam berat timbal $(\mathrm{Pb})$ serta struktur mikroanatomi ctenidia dan kelenjar pencernakan (hepar) Anodonta woodiana Lea., di Sungai Serang Hilir Waduk Kedung Ombo. BioSMART. 7(2), 136-142. 
